\title{
Dose-dependent effects of adiponectin on ADAMTS-9 gene expression in human chondrocytes
}

\author{
Yaykasli $\mathrm{KO}^{1}$, Hatipoglu $\mathrm{OF}^{2}$, Yaykasli E², Kaya E${ }^{4}$, Ozsahin $\mathrm{M}^{5}$, Uslu $\mathrm{M}^{6}$ \\ Duzce University, Faculty of Medicine, Department of Medical Genetics, Duzce, Turkey. \\ kursatyay@yahoo.com
}

\begin{abstract}
OBJECTIVE: A disintegrin and metalloproteinase with thrombospondin motifs (ADAMTS), comprising of 19 members is a family of peptidases. They have several vital functions in physiological and pathological processes in organisms. ADAMTS-9 has aggrecanolytic activity and is responsible for degradation of aggrecan mainly in articular cartilage. It is known that adiponectin is the most abundantly secreted adipokine (adipocytokines), and the characteristics of adiponectin have not been elucidated yet. It was assumed that adiponectin has antiinflammatory effect before. However, an inflammatory feature of adiponectin was shown in researches. In our study, the effect of adiponectin on ADAMTS- 9 gene expression in primary human chondrocytes was investigated. METHODS: Primary human chondrocytes were exposed to adiponectin at $1,4,8$ and $12 \mu \mathrm{g} / \mathrm{ml}$ doses for certain time period. Total RNA was isolated and reverse-transcribed by random primer after incubation. ADAMTS-9 and $\beta$-actin genes expression levels were determined using real-time polymerase chain reaction (qRT-PCR). RESULTS: The highest upregulation of ADAMTS-9 gene expression level was found at $12 \mu \mathrm{g} / \mathrm{ml}$ dose of adiponectin and $48 \mathrm{~h}$ incubation.

CONCLUSION: Adiponectin is the key element in the maintenance of cartilage homeostasis. Similarly, the involvement of adiponectin in articular inflammatory diseases was demonstrated in detail. These findings bring adiponectin into central place in the research to develop adiponectin based new therapy methods for arthritic diseases. Together with these findings, our results suggest that adiponectin may be involved in the degradation of articular cartilage by increasing ADAMTS-9 gene expression (Tab. 1, Fig. 3, Ref. 35). Text in PDF www.elis.sk. KEY WORDS: adiponectin, ADAMTS-9, human chondrocytes.
\end{abstract}

\section{Introduction}

A member of proteases family called ADAMTS (A disintegrin and metalloproteinase with thrombospondin motifs) has 19 members. It has been demonstrated that ADAMTSs are involved in numerous vital physiological and pathological processes especially connective tissue degradation in the organism since characterization of the first member of ADAMTS (ADAMTS-1) in 1997 $(1,2)$. The structures and functions of ADAM and ADAMTS are

${ }^{1}$ Duzce University, Faculty of Medicine, Department of Medical Genetics, Duzce, Turkey, ${ }^{2}$ Okayama University, Graduate School of Health Science, Department of Medical Technology, Okayama, Japan, ${ }^{3}$ Duzce University, Institute of Health Science, Department of Medical Biology and Genetics, Duzce, Turkey, ${ }^{4}$ Duzce University, Faculty of Medicine, Department of Medical Pharmacology, Duzce, Turkey, ${ }^{5}$ Duzce University, Faculty of Medicine, Department of Physical Medicine and Rehabilitation, Duzce, Turkey, and ${ }^{6}$ Duzce University, Faculty of Medicine, Department of Orthopedics, Duzce, Turkey

Address for correspondence: K.O. Yaykasli, PhD, Duzce University, Tip Fakültesi, Department of Medical Genetics, 81620 Konuralp, Duzce, Turkey.

Phone: +90.533 .7775021$

Acknowledgements: This study was supported by TUBITAK (The Scientific and Technical Research Council of Turkey), (Project Number: SBAG/111S218). similar. However, ADAMTSs have several thrombospondin type-1 motifs at $\mathrm{C}$-terminal region, while ADAMs having transmembrane and cytoplasmic domains. Nowadays, ADAMTSs entitled as a family of metalloproteinases containing one or more thrombospondin type 1 motifs interact with the component of extracellular matrix (ECM) $(3,4)$. ADAMTS-9 is a member of zinc-dependent metalloproteinase ADAMTS family and characterized in 2000. The location (3p21.1-p14.3) of ADAMTS-9 gene has gain importance due to frequently chromosomal rearrangement region. So, ADAMTS9 has shown to have pivotal role in several types of cancers especially renal cancer $(5,6)$. Besides, ADAMTS-9 has aggrecanolytic activity, and is responsible for the degradation of aggrecan, mainly in articular cartilage $(7,8)$.

Adiponectin, one of the early characterized adipokines was discovered by Scherer et al in 1995. Adiponectin, a 244-aminoacid-long polypeptide is the most abundantly secreted adipokine from adipose tissue and has biological effects through two distinguished receptors called AdipoR1 and AdipoR2 located in the joint cartilage, bone and synovial tissue $(9,10)$. Adiponectin plays an important role not only in insulin sensitivity but also maintenance of cartilage homeostasis. It was clarified that adiponectin has potential to act in matrix degradation and inflammation in the human joint by our group (11). So, adiponectin gains importance in arthritic disease investigations. However, there is no research 


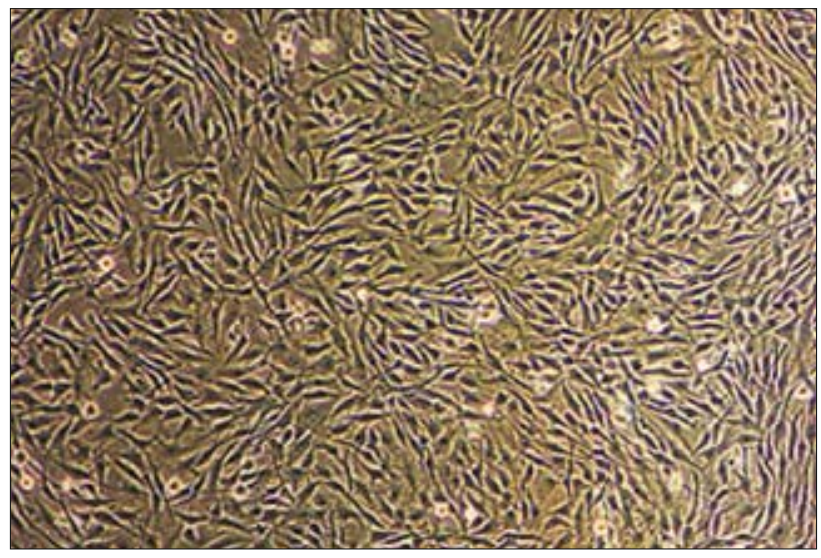

Fig. 1. The confluent primary human chondrocytes.

to investigate putative relationship between adiponectin and ADAMTS gene family. In this study, we aimed to clarify the relationship between ADAMTS-9 and adiponectin of primary human chondrocytes.

\section{Materials and methods}

\section{RNA isolation and cDNA synthesis}

Recombinant human adiponectin was purchased from Enzo Life Sciences (Farmingdale, NY) and dissolved in PBS (phosphate buffered saline) (Sigma, St. Louis, MO) The obtained stock solution was stored at $-80{ }^{\circ} \mathrm{C}$ until usage. Prior to use, the solution was diluted to the desired concentrations.

Normal human chondrocyte (NHAC-kn) cells were obtained from Lonza (Walkersville, MD), and plated in growth medium (CC-3216, Lonza, Walkersville, MD) at $37{ }^{\circ} \mathrm{C}$ and $5 \% \mathrm{CO}_{2}$ conditions. After incubation for 4-7 days, the cells were divided into 6 or 12 well flask using subculture kit (CC-3233, Lonza, Walkersville, MD). Confluent chondrocytes (Fig. 1) were exposed to certain concentration of recombinant adiponectin $(1,4,8$ and 12 $(\mu \mathrm{g} / \mathrm{ml}))$ for $6,12,24$ and 48 hours.

After the chondrocytes were treated with adiponectin for a certain period of time, the medium was discarded, the cells were washed 3 times with PBS, and total RNA was isolated with TriPure Reactive (Roche Diagnostics, Mannheim, Germany). The obtained total RNA concentration was measured and the complementary DNA (cDNA) was re-transcribed from $2 \mu \mathrm{g}$ total RNA using random primer and High Capacity cDNA Reverse Transcription Kit (Applied Biosystems, Foster City, CA).

Tab. 1. Primers and Tm used for qRT-PCR analysis.

\begin{tabular}{|c|c|c|c|}
\hline Gen & $\mathrm{Tm}$ & Primer & Primer Sekansi \\
\hline \multirow{2}{*}{ ADAMTS-9 } & \multirow{2}{*}{55} & forward & 5'-GGACAAGCGAAGGACATCC-3" \\
\hline & & reverse & 5'-ATCCATCCATAATGGCTTCC-3" \\
\hline \multirow{2}{*}{$\beta$-actin } & \multirow{2}{*}{55} & forward & 5'-TTCCTGGGCATGGAGTCCT -3' \\
\hline & & reverse & 5'-AGGAGGAGCAATGATCTTGATC-3' \\
\hline
\end{tabular}

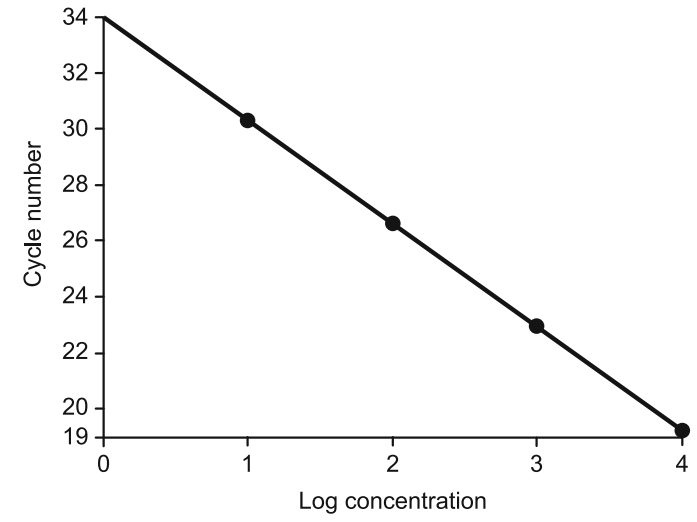

Fig. 2. Standard curve.

Quantitative Real Time-Polymerase Chain Reaction ( $q R T-P C R$ )

The expression levels of ADAMTS- 9 and $\beta$-actin were measured by RT-PCR methods as describe before (12). Briefly, a total of $20 \mu 1$ mixture consisting of 1x LightCycler FastStart DNA Master SYBR Green (Roche Diagnostics, Mannheim, Germany) obtained cDNA, proper primers and $\mathrm{H}_{2} \mathrm{O}$ was subjected to RTPCR amplification using LightCycler® Nano System (Roche Diagnostics, Mannheim, Germany). For the RT-PCR protocol, a 3-step cycle $\left(20 \mathrm{~s}\right.$ at $95{ }^{\circ} \mathrm{C}, 20 \mathrm{~s}$ melting temperature (Tm) and $20 \mathrm{~s}$ at $72{ }^{\circ} \mathrm{C}$ ) was repeated 45 times after $95{ }^{\circ} \mathrm{C}$ for $600 \mathrm{~s}$ preincubation. Primers and Tm values used in the amplifications are given in Table 1. Negative controls were used to check samples. In negative control, nuclease-free water was added to reactions tubes instead of RNA templates. The obtained experimental data were analyzed using absolute standard curve method (Fig. 2). The amplification of housekeeping gene, $\beta$-actin, was used as internal standard to normalizing ADAMTS-9 gene expression level. For each samples, the copy numbers of ADAMTS-9 and $\beta$-actin were calculated using template based standard curve, and ADAMTS-9/ $\beta$-actin ratios were given to relative gene expression level.

\section{Statistical analysis}

PASW 18 (version 18.0 for Windows; SPSS Inc., Chicago, IL, USA) program was used for data evaluation. For statistical analysis, Mann Whitney $U$ test was used. The values are given as mean value \pm SEM. The difference was accepted statistically significant if $\mathrm{p}$ values were less than 0.05 .

\section{Results}

To analyze the putative role of adiponectin on ADAMTS-9 gene expression, primary human chondrocytes were treated in the presence of certain doses $(1,4,8$ and $12(\mu \mathrm{g} / \mathrm{ml}))$ of adiponectin for $6,12,24$ and 48 hours. At the end of the incubation, ADAMTS-9 gene expression level was analyzed by RT-PCR and standardized according to $\beta$-actin expression level. The relative increase in ADAMTS-9 gene expression was obtained by com- 

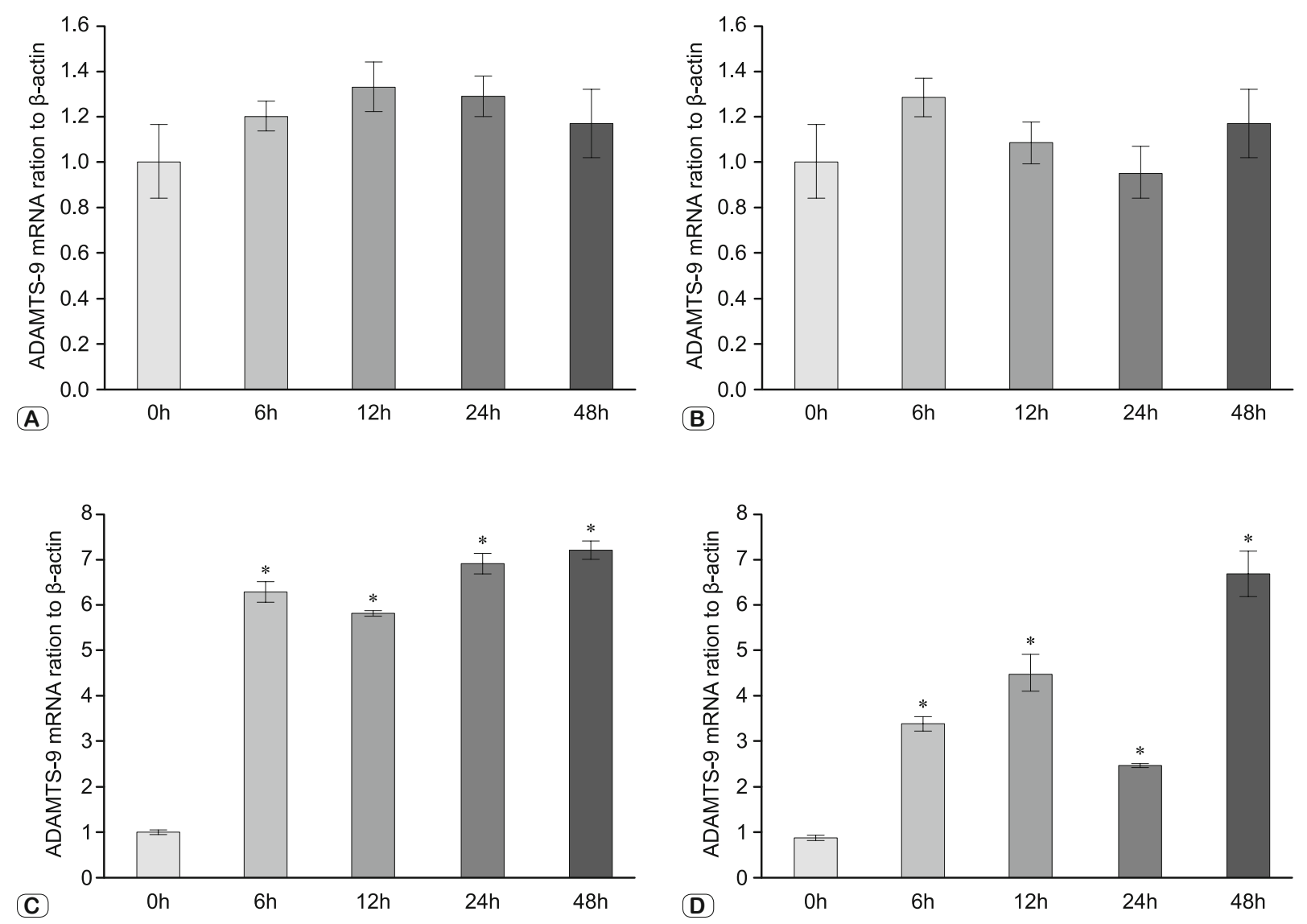

Fig. 3. The effect of adiponectin on ADAMTS-9 gene expression level. Human primer chondrocytes incubated with $1 \mu \mathrm{g} / \mathrm{ml}(\mathrm{A}), 4 \mu \mathrm{g} / \mathrm{ml}(\mathrm{B}), 8$ $\mu \mathrm{g} / \mathrm{ml}$ (C) and $12 \mu \mathrm{g} / \mathrm{ml}$ (D) for 6, 12, 24 and 48 hours, and $A D A M T S-9$ gene expression level investigated by RT-PCR method. The results are standardized by $\beta$-actin. There was no significant upregulation at 1 and $4 \mu \mathrm{g} / \mathrm{ml}$ doses. However, $A D A M T S-9$ gene expression level was statistically upregulated at 8 and $12 \mu \mathrm{g} / \mathrm{ml}$ doses. The highest upregulation was obtained at $12 \mu \mathrm{g} / \mathrm{ml}$ for 48 hours (* p $<0.05$; significance compared to control).

paring ADAMTS-9 gene expression levels in chondrocytes with adiponectin-free conditions.

There was no statistically significant increase in ADAMTS-9 gene expression level for 1 and $4 \mu \mathrm{g} / \mathrm{ml}$ adiponectin treatment (Figs 3A and 3B). However, ADAMTS-9 gene expression level was increased at the dose of 8 and $12(\mu \mathrm{g} / \mathrm{ml})$ (Figs 3C and 3D). The highest up-regulation was obtained at $12 \mu \mathrm{g} / \mathrm{ml}$ adiponectin incubation for 48 hours.

\section{Discussion}

Adiponectin effectively plays vital roles in a number of metabolic processes especially in inflammatory pathological circumstances in organisms. The involvement of adiponectin in diseases such as cardiovascular diseases, endothelial dysfunction, type 2 diabetes, metabolic syndrome, and rheumatic diseases has been proven up to date $(13,14)$. Although, the hypothesis that adiponectin shows anti-inflammatory characteristic was suggested, the catabolic effect of adiponectin with inflammatory features in arthritic diseases was proven by several groups $(15,16)$. In addition,
Lee et al (17) has suggested that adiponectin takes more important role than IL-1 $\beta$ in joint destruction. Therefore, the underlying mechanism for the pleiotropic action of adiponectin should be clarified. For this aim, primary human chondrocytes were exposed to recombinant adiponectin at physiological and pathological doses (18). The highest ADAMTS-9 upregulation was obtained at $12(\mu \mathrm{g} /$ $\mathrm{ml})$ dose for $48 \mathrm{~h}$ incubation.

Irreversible destruction of joint cartilage components such as aggrecan is a critical event for not only rheumatoid arthritis (RA) but also osteoarthritis (OA). It was clarified that aggrecan destruction is the result of elevated agrecanases activity by inflammation $(19,20)$. Obesity identified as accumulation of excessive amounts of adipose tissue is assumed one of the risk factors for RA and OA. Adipose tissue contributes to the development of inflammation in diseases by secreting adipokines. The mechanism of adipokines induced-ADAMTS gene expression in chondrocytes and chondrosarcoma was demonstrated before by our group (21-23). An up-regulated adiponectin level in both RA and OA patients was reported $(24,25)$. After these findings, the researchers have focused on the mechanism of adiponectin caused joint destruction. It was 
demonstrated that adiponectin increased inflammatory interleukin-6 (IL-6) (26) and interleukin-8 (27) in synovial fibroblast cells. Besides, the upregulation of matrix metalloproteinase (MMP) -1 and -13 genes expression level in fibroblast-like cell was demonstrated by Choi et al (28). The relationship between adiponectin and other MMPs (MMP-2 and $M M P-3)$ was also showed by other researchers $(29,30)$.

However, there is no investigation apart from our data to demonstrate the putative effect of adiponectin on ADAMTSs gene expression level in literature. The dose-dependent catabolic effect of the other adipokines (leptin, resistin and visfatin) has been proven by our group (31-33). It was also hypothesized that adiponectin plays an important role as much as cytokines like IL-1 $\beta$ in the cartilage destruction. To clarify the putative effects on ADAMTS expression level, the primary human chondrocytes were incubated with adiponectin for certain time points. The highest upregulation (nearly 8 times more) was obtained at $12 \mu \mathrm{g} / \mathrm{ml}$ dose for $48 \mathrm{~h}$ incubation. Similar data was obtained before by Lee et al (17). The human endothelial cells and osteoblasts were stimulated with adiponectin (1 or $10 \mu \mathrm{g} / \mathrm{ml}$ ) by them. The upregulation of $I L-6$, $I L-8, M M P-1$, and $M M P-13$ was much higher than with IL-1 $\beta$ $(0.1 \mathrm{ng} / \mathrm{ml})$ stimulation. As a result of these experimental data, it may be speculated that adiponectin may be involved in inflammatory arthritic diseases by increasing ADAMTS-9 expression level. However, the other ADAMTSs should be investigated to clarify the mechanism. Anyway, our results supported the hypothesis that adiponectin has a potential to be a marker for arthritic disease $(34,35)$. So, adiponectin might be targeted to get new therapy for arthritic diseases.

\section{References}

1. Kuno K, Kanada N, Nakashima E, Fujiki F, Ichimura F, Matsushima K. Molecular cloning of a gene encoding a new type of metalloproteinasedisintegrin family protein with thrombospondin motifs as an inflammation associated gene. J Biol Chem 1997; 272 (1): 556-562.

2. Hurskainen TL, Hirohata S, Seldin MF, Apte SS. ADAM-TS5, ADAM-TS6, and ADAM-TS7, novel members of a new family of zinc metalloproteases. General features and genomic distribution of the ADAM-TS family. J Biol Chem 1999; 274: 25555-25563.

3. Takeda S. ADAM and ADAMTS Family Proteins and Snake Venom Metalloproteinases: A Structural Overview. Toxins (Basel) 2016; 8 (5).

4. Yaykasli KO, Oohashi T, Hirohata S, Hatipoglu OF, Inagawa K, Demircan K, Ninomiya Y. ADAMTS9 activation by interleukin 1 beta via NFATc1 in OUMS-27 chondrosarcoma cells and in human chondrocytes. Mol Cell Biochem 2009; 323 (1-2): 69-79.

5. Clark ME, Kelner GS, Turbeville LA, Boyer A, Arden KC, Maki RA. ADAMTS9, a novel member of the ADAM-TS/metallospondin gene family. Genomics 2000; 67: 343-350.

6. Apte SS. A disintegrin-like and metalloprotease (reprolysin-type) with thrombospondin type 1 motif (ADAMTS) superfamily: functions and mechanisms. J Biol Chem 2009; 284 (46): 31493-31497.

7. Yaykasli KO, Yaykasli E, Ozsahin M, Uslu M, Kaya E. Leptin increases ADAMTS9 gene expression in human chondrocytes. Curr Opinion Biotechnol 2013; (24): S99.
8. Murphy G, Nagase H. Reappraising metalloproteinases in rheumatoid arthritis and osteoarthritis: destruction or repair. Nat Clin Pract Rheumatol 2008; 4 (3): 128-135.

9. Scherer PE, Williams S, Fogliano M, Baldini G, Lodish HF. A novel serum protein similar to C1q, produced exclusively in adipocytes. J Biol Chem 1995; 270 (45): 26746-26749.

10. Kadowaki T, Yamauchi T. Adiponectin and adiponectin receptors. Endocr Rev 2005; 26: 439-451.

11. Yaykasli K, Dogan M, Hatipoglu O, Yaykasli E, Kaya E, Ozsahin M, Uslu M. Effect of adiponectin on a disintegrin and metalloproteinase with thrombospondin motifs- 9 gene expression in human chondrocytes (CCR5P. 257). J Immunol 2014; 192 (Suppl 1): 181.11.

12. Hatipoglu OF, Hirohata S, Yaykasli KO, Cilek MZ, Demircan K, Shinohata R, Yonezawa T et al. The 3'-untranslated region of ADAMTS1 regulates its mRNA stability. Acta Med Okayama 2009; 63 (2): 79-85.

13. Ye R, Scherer PE. Adiponectin, driver or passenger on the road to insulin sensitivity? Mol Metab 2013; 2 (3): 133-141.

14. Ehling A, Schäffler A, Herfarth H, Tarner IH, Anders S, Distler O, Paul G et al. The potential of adiponectin in driving arthritis. J Immunol 2006; 176 (7): 4468-4478.

15. Chen TH, Chen L, Hsieh MS, Chang CP, Chou DT, Tsai SH. Evidence for a protective role for adiponectin in osteoarthritis. Biochim Biophys Acta 2006; 1762: 711-718.

16. Francin PJ, Abot A, Guillaume C, Moulin D, Bianchi A, Gegout-Pottie P, Jouzeau JY et al. Association between adiponectin and cartilage degradation in human osteoarthritis. Osteoarthritis Cartilage 2014; 22 (3): 519-526.

17. Lee YA, Ji HI, Lee SH, Hong SJ, Yang HI, Chul Yoo M, Kim KS. The role of adiponectin in the production of IL-6, IL-8, VEGF and MMPs in human endothelial cells and osteoblasts: implications for arthritic joints. Exp Mol Med 2014; 46: e72.

18. Merl V, Peters A, Oltmanns KM, Kern W, Born J, Fehm HL, Schultes B. Serum adiponectin concentrations during a 72-hour fast in overand normal-weight humans. Int J Obes (Lond) 2005; 29 (8): 998-1001.

19. Yaykasli KO, Yaykasli E, Ataoğlu S, Özsahin M, Memisoğullari R, Çelebi E, Uçgun T et al. The frequency of omentin Val109Asp polymorphism and the serum level of omentin in patients with Rheumatoid Arthritis. Acta Med Mediterr 2013; 29: 521-526.

20. Inagawa K, Oohashi T, Nishida K, Minaguchi J, Tsubakishita T, Yaykasli KO, Ohtsuka A et al. Optical imaging of mouse articular cartilage using the glycosaminoglycans binding property of fluorescent-labeled octaarginine. Osteoarthritis Cartilage 2009; 17 (9): 1209-1218.

21. Hatipoglu OF, Yaykasli KO, Doğan M, Yaykasli E, Kaya E, Özsahin M, Uslu M. Leptin induction of aggrecanases- 1 and -2 genes expression in human chondrocytes is mediated by $\mathrm{p} 38$ mitogen-activated protein kinase pathway (CCR5P.265). J Immunol 2014; 192 (Suppl 1): 181.19.

22. Yaykasli KO. Visfatin promotes a disintegrin and metalloproteinase with thrombospondin motifs- 5 gene expression through p38 MAPK and NF-кB pathways in human chondrocytes. FEBS J 2016; 283: 50.

23. Hatipoglu OF, Yaykasli KO, Yaykasli E, Kaya E, Özsahin M, Uslu $\mathbf{M}$, Yildirim $\mathrm{K}$ et al. Resistin induces a disintegrin and metalloproteinase with thrombospondin motifs-4 gene expression in human chondrosarcoma cell line. Eur J Cancer 2014; 50: S81.

24. Lee YH, Bae SC. Circulating adiponectin and visfatin levels in rheumatoid arthritis and their correlation with disease activity: A meta-analysis. Int J Rheum Dis 2017. doi: 10.1111/1756-185X.13038. 


\section{6-390}

25. Koskinen A, Juslin S, Nieminen R, Moilanen T, Vuolteenaho K, Moilanen E. Adiponectin associates with markers of cartilage degradation in osteoarthritis and induces production of proinflammatory and catabolic factors through mitogen-activated protein kinase pathways. Arthritis Res Ther 2011; 13 (6): R184.

26. Tang CH, Chiu YC, Tan TW, Yang RS, Fu WM. Adiponectin enhances IL-6 production in human synovial fibroblast via an AdipoR1 receptor, AMPK, p38, and NF-кB pathway. J Immunol 2007; 179: 5483-5492.

27. Kitahara K, Kusunoki N, Kakiuchi T, Suguro T, Kawai S. Adiponectin stimulates IL-8 production by rheumatoid synovial fibroblasts. Biochem Biophys Res Commun 2009; 378 (2): 218-223.

28. Choi HM, Lee YA, Lee SH, Hong SJ, Hahm DH, Choi SY, Yang HI et al. Adiponectin may contribute to synovitis and joint destruction in rheumatoid arthritis by stimulating vascular endothelial growth factor, matrix metalloproteinase-1, and matrix metalloproteinase-13 expression in fibroblast-like synoviocytes more than proinflammatory mediators. Arthritis Res Ther 2009; 11: R161.

\section{Tong KM, Chen CP, Huang KC, Shieh DC, Cheng HC, Tzeng}

CY, Chen KH et al. Adiponectin increases MMP-3 expression in human chondrocytes through AdipoR1 signaling pathway. J Cell Biochem 2011; 112 (5): 1431-1440.
30. Miksztowicz V, Fernandez Machulsky N, Lucero D, Fassio E, Schreier L, Berg G. Adiponectin predicts MMP-2 activity independently of obesity. Eur J Clin Invest 2014; 44 (10): 951-957.

31. Yaykasli KO, Hatipoglu OF, Yaykasli E, Yildirim K, Kaya E, Ozsahin M, Uslu M et al. Leptin induces ADAMTS-4, ADAMTS-5, and genes expression by mitogen-activated protein kinases and NF-KB signaling pathways in human chondrocytes. Cell Biol Int 2015; 39 (1): 104-112.

32. Hatipoglu OF, Yaykasli KO, Dogan M, Yaykasli E, Bender O, Yasar T, Tapan S et al. NF- $\kappa$ B and MAPKs are involved in resistin caused ADAMTS-5 induction in Human Chondrocytes. Clin Invest Med 2015; 38 (4): E248-E254.

33. Yaykasli KO, Doğan M, Hatipoğlu ÖF, Yaykasli E, Kaya E, Özsahin M, Uslu M. Visfatin increases the activity of aggrecanases-1 and -2 in human chondrocytes. J Immunol 2014; 192 (Suppl 1):181.18.

34. Filkova M, Liskova M, Hulejova H, Haluzik M, Gatterova J, Pavelkova $A$ et al. Increased serum adiponectin levels in female patients with erosive compared with non-erosive osteoarthritis. Ann Rheum Dis 2009; 68: 295-296.

35. Chen X, Lu J, Bao J, Guo J, Shi J, Wang Y. Adiponectin: a biomarker for rheumatoid arthritis? Cytokine Growth Factor Rev 2013; 24 (1): 83-89.

Received January 30, 2017. Accepted March 6, 2017. 